\title{
Ocular Pathogens, Eye Infections, and Cosmetics Periodic Update (July 1, 2016 to June 30, 2017)
}

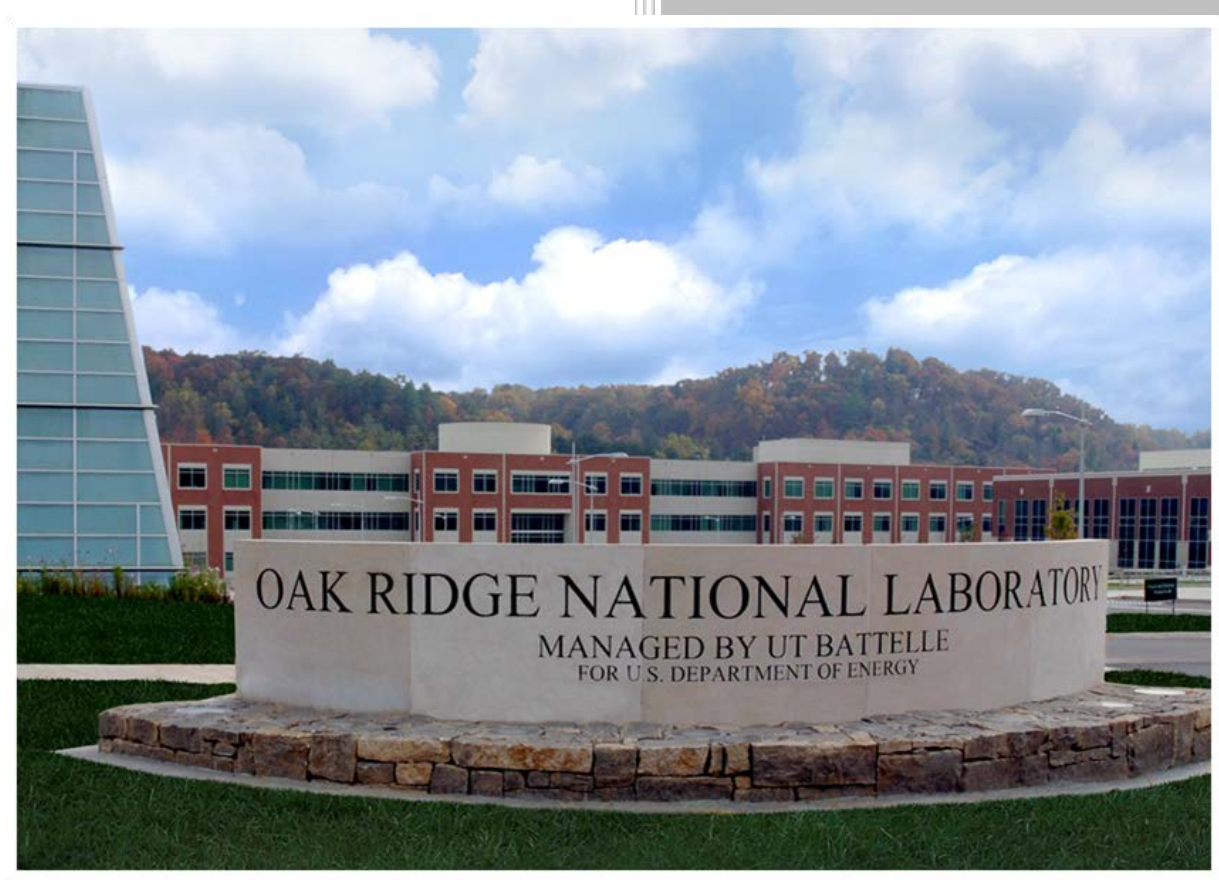

Approved for public release. Distribution is unlimited.
Anthony Q. Armstrong Jennifer L. Goldberg Marilyn E. Langston Dana F. Glass-Mattie October 2017 


\title{
DOCUMENT AVAILABILITY
}

Reports produced after January 1, 1996, are generally available free via US Department of Energy (DOE) SciTech Connect.

\section{Website www.osti.gov}

Reports produced before January 1, 1996, may be purchased by members of the public from the following source:

\author{
National Technical Information Service \\ 5285 Port Royal Road \\ Springfield, VA 22161 \\ Telephone 703-605-6000 (1-800-553-6847) \\ TDD 703-487-4639 \\ Fax 703-605-6900 \\ E-mail info@ntis.gov \\ Website http://classic.ntis.gov/
}

Reports are available to DOE employees, DOE contractors, Energy Technology Data Exchange representatives, and International Nuclear Information System representatives from the following source:

Office of Scientific and Technical Information

PO Box 62

Oak Ridge, TN 37831

Telephone 865-576-8401

Fax 865-576-5728

E-mail reports@osti.gov

Website http://www.osti.gov/contact.html

This report was prepared as an account of work sponsored by an agency of the United States Government. Neither the United States Government nor any agency thereof, nor any of their employees, makes any warranty, express or implied, or assumes any legal liability or responsibility for the accuracy, completeness, or usefulness of any information, apparatus, product, or process disclosed, or represents that its use would not infringe privately owned rights. Reference herein to any specific commercial product, process, or service by trade name, trademark, manufacturer, or otherwise, does not necessarily constitute or imply its endorsement, recommendation, or favoring by the United States Government or any agency thereof. The views and opinions of authors expressed herein do not necessarily state or reflect those of the United States Government or any agency thereof. 
Environmental Sciences Division

\title{
OCULAR PATHOGENS, EYE INFECTIONS, AND COSMETICS \\ Periodic Update (July 1, 2016 to June 30, 2017)
}

\author{
Anthony Q. Armstrong \\ Jennifer L. Goldberg \\ Marilyn E. Langston \\ Dana F. Glass-Mattie
}

Date Published: October 2017

\author{
Prepared by \\ OAK RIDGE NATIONAL LABORATORY \\ Oak Ridge, TN 37831-6283 \\ managed by \\ UT-BATTELLE, LLC \\ for the \\ US DEPARTMENT OF ENERGY \\ under contract DE-AC05-00OR22725
}




\section{Ocular Pathogens, Eye Infections, and Cosmetics - Periodic Update (July 1, 2016 to June 30, 2017)}

\section{Executive Summary}

A PubMed literature search was conducted to support analyses and investigations of the relationship between microorganisms associated with human eye infections (including opportunistic pathogens) and cosmetics. Key terms for PubMed literature searches included; microbial genera and species of interest (bacteria, viruses, fungi, protozoans, parasites), opportunistic pathogens, human eye disease and infection, human ocular infections, specific eye diseases (keratitis, conjunctivitis, etc.), eye accidents, eye surgery, contacts, infants, pregnant women, geriatric, immunocompromised, HIV and polymicrobial. The number of journal articles for defined searches was summarized and journal citations and abstracts were cataloged and incorporated into a searchable information system (MS Access). A periodic update to the literature searches was conducted in July 2017 and observations from the update indicate the most commonly associated bacteria with eye infections/diseases were Staphylococcus sp., Chlamydia sp. and Pseudomonas sp. Also, the literature searches indicate the most commonly associated fungi with eye infections/diseases were Fusarium sp., Aspergillus sp. and Candida sp. A relative rank of occurrence of microorganisms associated with eye infections/disease in the literature citations was; Staphylococcus aureus, Chlamydia trachomatis, Cytomegalovirus, Herpes zoster virus, Pseudomonas aeruginosa, Staphylococcus epidermidis, Acanthamoeba sp., Fusarium sp., E. coli and Mycobacterium tuberculosis. Literature searches for opportunistic microorganisms and emerging pathogens for this update identified several articles on fungi, Bacillus sp. (primarily B. cereus), Haemophilus influenzae and Human Papillomavirus (HPV) associated with eye infections/diseases. Although the literature searches focused on microorganisms, key eye diseases noted in the citations were keratitis, conjunctivitis, corneal ulcers, endophthalmitis and keratoconjunctivitis. 


\section{Ocular Pathogens, Eye Infections, and Cosmetics - Periodic Update (July 1, 2016 to June 30, 2017)}

A PubMed literature search was conducted to support analyses and investigations of the relationship between microorganisms associated with human eye infections (including opportunistic pathogens) and cosmetics. Key search terms were identified by U.S. Food and Drug Administration, Center for Food Safety and Nutrition (CFSAN), Office of Cosmetics and Colors (OCAC) and Oak Ridge National Laboratory (ORNL) Human Health Risk and Environmental Analysis staff. The search terms included; microbial genera and species of interest (bacteria, viruses, fungi, protozoans, parasites), opportunistic pathogens, human eye disease and infection, human ocular infections, specific eye diseases (keratitis, conjunctivitis, etc.), eye accidents, eye surgery, contacts, infants, pregnant women, geriatric, immunocompromised, HIV and polymicrobial. This report describes results from literature searches conducted of PubMed/Medline and MeSH databases covering the period of July 1, 2016 to June 30, 2017. Periodic updates of the literature searches and the associated information system are planned to maintain current information.

The number of journal articles for defined search terms were compiled and summarized. In addition to collecting numbers of journal articles (total of 1643 articles), relevant citations and associated abstracts were cataloged and incorporated into a searchable MS Access information system. There are 1054 citations and associated abstracts added to the information system during this update. Results of the literature searches for this periodic update indicate the most commonly associated bacteria with eye infections/diseases are Staphylococcus sp., Chlamydia sp., and Pseudomonas sp. Table 1 lists the key bacteria identified in the literature searches and provides a relative rank of occurrence with respect to other bacteria associated with eye infections. Also, a relative rank of occurrence of each genus or species of bacteria among all key microorganisms from the literature searches is included. Occurrence of Staphylococcus sp. and Chlamydia sp. ranked first and second respectively when compared to all key microorganisms from the literature searches. Results from literature searches of opportunistic microorganisms for this update identified several articles on fungi, Bacillus sp. (primarily B. cereus), Haemophilus influenzae and Human Papillomavirus (HPV) associated with eye infections.

Table 2 lists the key fungi identified in the literature searches and provides a relative rank of occurrence with respect to other fungi associated with eye infections. Results of the literature searches indicate the most commonly associated fungi with eye infections/diseases are Fusarium sp., Aspergillus sp. and Candida sp. Also, a relative rank of occurrence of each genus or species of fungi among all key microorganisms from the literature searches is included. When compared to all key microorganisms from the literature searches, Fusarium sp. ranks \#8 and Candida sp.is \#13.

Table 3 lists the key virus, protozoa, and parasites identified in the literature searches. A relative rank of occurrence with respect to other microorganisms associated with eye infections indicates the most common viruses associated with eye infections are Cytomegalovirus and Herpes zoster virus. Acanthamoeba sp. and Onchocerca sp. were commonly associated with eye infections as well as the parasite Toxoplasma gondii which was the fourth most commonly identified in this group. When 
compared to all key microorganisms from the literature searches, Cytomegalovirus ranks \#3, Herpes zoster virus is \#4, Acanthamoeba sp. is \#7, and Toxoplasma gondii is \#11 in association with eye infections.

Table 1. Summary of key bacteria identified in literature searches of PubMed from July 1, 2016 to June 30, 2017 for microorganisms associated with eye infections. Relative rank of each bacterial species based on occurrence in literature citations to other bacteria and all microorganisms is provided.

\begin{tabular}{||l|c|c||}
\hline \multicolumn{1}{|c|}{ Search Term (Bacteria) } & $\begin{array}{c}\text { Relative Rank to other } \\
\text { Bacteria }\end{array}$ & $\begin{array}{c}\text { Relative Rank among all } \\
\text { Microorganisms }\end{array}$ \\
\hline \hline Acinetobacter sp. & 14 & 19 \\
\hline Alcaligenes faecalis & 20 & 36 \\
\hline Bacillus & 7 & 14 \\
B. cereus subtilis & 19 & 33 \\
\hline Chlamydia trachomatis & 2 & 2 \\
\hline Corynebacterium & 9 & 15 \\
\hline E. coli & 5 & 9 \\
\hline Klebsiella sp. & 8 & 12 \\
\hline Moraxella sp. & 17 & 26 \\
\hline Mycobacterium tuberculosis & 6 & 10 \\
\hline Neisseria gonorrhea & 10 & 17 \\
\hline Proteus mirabilis & 13 & 20 \\
\hline Pseudomonas aeruginosa & 3 & 5 \\
\hline Serratia marcescens & 12 & 18 \\
\hline Staphylococcus & & 1 \\
S. aureus & 1 & 6 \\
S. epidermidis & 4 & 32 \\
S. haemolyticus & 18 & 27 \\
\hline Streptococcus & 16 & 25 \\
\hline S. pyoumenes & 15 & 21 \\
\hline Treponema pallidum & 11 & \\
\hline
\end{tabular}


Table 2. Summary of key fungi identified in literature searches of PubMed from July 1, 2016 to June 30, 2017 for microorganisms associated with eye infections. Relative rank of each fungus based on occurrence in literature citations to other fungi and all microorganisms is provided.

\begin{tabular}{||l|c|c|}
\hline \multicolumn{1}{|c|}{ Search Term (Fungi) } & $\begin{array}{c}\text { Relative Rank to other } \\
\text { Fungi }\end{array}$ & $\begin{array}{c}\text { Relative Rank among all } \\
\text { Microorganisms }\end{array}$ \\
\hline \hline Alternaria & 7 & 28 \\
\hline Ascomycota & 5 & 23 \\
\hline Aspergillus & & \\
A. fumigatus & 4 & 24 \\
A. flavus & 2 & 16 \\
A. niger & 9 & 31 \\
\hline Candida albicans & 3 & 13 \\
\hline Cladosporium & 10 & 34 \\
\hline Curvularia & 6 & 30 \\
\hline Fusarium sp. & 1 & 8 \\
\hline Penicillium & 8 & 29 \\
\hline
\end{tabular}

Table 3. Summary of other key microorganisms identified in literature searches of PubMed from July 1, 2016 to June 30, 2017 for microorganisms associated with eye infections. Relative rank of each virus, protozoa, or parasite based on occurrence in literature citations to other microorganisms and to all microorganisms is provided.

\begin{tabular}{|l|c|c||}
\hline \multicolumn{1}{|c|}{ Search Term (others) } & Relative Rank to others & $\begin{array}{c}\text { Relative Rank among all } \\
\text { Microorganisms }\end{array}$ \\
\hline \hline Acanthamoeba sp. & 3 & 7 \\
\hline Cytomegalovirus & 1 & 3 \\
\hline Herpes zoster virus & 2 & 4 \\
\hline Leishmania sp. & 6 & 35 \\
\hline Onchocerca sp. & 5 & 22 \\
\hline $\begin{array}{l}\text { Spirometra sp. } \\
\text { (previously Sparganum sp.) }\end{array}$ & 7 & 37 \\
\hline Toxoplasma gondii & 4 & 11 \\
\hline
\end{tabular}


In addition, Table 4 lists the top 10 microorganisms identified in this update literature search by rank order of occurrence in the citations compared to all other microorganisms.

Table 4. Top ten microorganisms in this periodic update (July 1, 2016 to June 30, 2017) by rank order of occurrence in the citations from literature searches of PubMed for microorganisms associated with eye infections.

\begin{tabular}{||l|c||}
\hline \multicolumn{1}{||c|}{ Microorganisms } & $\begin{array}{c}\text { Relative Rank among all } \\
\text { Microorganisms }\end{array}$ \\
\hline Staphylococcus aureus & 1 \\
\hline Chlamydia trachomatis & 2 \\
\hline Herpes zoster virus & 4 \\
\hline Cytomegalovirus & 3 \\
\hline Pseudomonas aeruginosa & 5 \\
\hline Staphylococcus epidermidis & 6 \\
\hline Acanthamoeba sp. & 7 \\
\hline Toxoplasma gondii & 8 \\
\hline Fusarium sp. & 9 \\
\hline E. coli & 10 \\
\hline
\end{tabular}

Several observations from this update of the literature search indicate prevalence of fungal related eye infections in citations when compared to previous updates. Emerging microbes of interest based on more prevalence in citations were Bacillus sp. (primarily B. cereus), Enterobacteriaceae (Enterobacter gergoviae), HPV and Haemophilus influenzae. Based on the citations from this literature search update, the occurrence of these microbes with eye infections is noteworthy.

Although the literature searches focused on microorganisms, information on eye diseases was also compiled. Table 5 lists the key eye diseases identified in the literature searches and the ranking of occurrence indicates keratitis is most commonly associated with microorganisms. Keratitis, conjunctivitis, corneal ulcers, endophthalmitis and keratoconjunctivitis round out the top five eye diseases in rank order that are associated with eye infections.

Table 5. Summary of key eye diseases identified in literature searches of PubMed from July 1, 2016 to June 30, 2017 for microorganisms associated with eye infections. Relative rank of each disease based on occurrence in literature citations is provided.

\begin{tabular}{|l|c|}
\hline \multicolumn{1}{|c|}{ Search Term (Diseases) } & Relative Rank to other Diseases \\
\hline \hline Anterior Uveitis & 7 \\
\hline Blebitis & 11 \\
\hline Blepharoconjuctivitis & 15 \\
\hline Conjunctivitis & 2 \\
\hline Corneal Erosion & 12 \\
\hline Corneal Ulcers & 3 \\
\hline Endophthalmitis & 4 \\
\hline Iritis & 9 \\
\hline Keratitis & 1 \\
\hline Keratoconjunctivitis & 5 \\
\hline Keratomycosis & 8 \\
\hline Ocular Rosacea & 10 \\
\hline
\end{tabular}




\begin{tabular}{|l|c|}
\hline \hline Orbital Cellulitis & 6 \\
\hline Preseptal Cellulitis & 14 \\
\hline Scleritis & 13 \\
\hline
\end{tabular}

\section{Microbial/Eye Infection Literature Information System}

To support analyses and investigations of the relationship between microorganisms associated with human eye infections (including opportunistic pathogens) and cosmetics, the citations and abstracts from the PubMed literature searches described above were assimilated in a literature inventory. Journal citations and abstracts from the PubMed literature searches were cataloged and entered into a MS Access database to support queries and additional analyses to investigate the relationships between human eye diseases and microorganisms. Within the MS Access database, queries were developed and export functionality was included to allow results from queries (lists of citations or citations including abstracts) to be exported. The information system also supports investigations of microbial eye infection occurrence and clinical information on pathogenicity.

Version 5 of the Microbial/Eye Infection information system (MS Access database) was delivered to FDA OCAC on September 25, 2017 via ftp. Version 5 contains 11,883 records. Based on discussions with FDA OCAC staff, additional functionality was incorporated to allow FDA OCAC staff to periodically update the database with information provided by ORNL. As part of the future updates, literature search terms will be reviewed and updated before the search is conducted. Quick turnaround literature searches for opportunistic microbial pathogens that are not currently included in the Microbial/Eye Infection information system will be added as requested by FDA OCAC. 
Appendix A.

Listing of microorganisms identified in literature searches from PubMed for microorganisms associated with eye infections by rank order of occurrence in the literature citations for the periodic searches.

\begin{tabular}{|c|c|c|c|c|}
\hline \multirow{2}{*}{ Microorganism } & \multicolumn{4}{|c|}{ Relative Rank to all other Microorganisms } \\
\hline & March 31, 2015 & October 31, 2015 & June 30, 2016 & June 30, 2017 \\
\hline Chlamydia trachomatis & 1 & 1 & 1 & 2 \\
\hline Staphylococcus aureus & 2 & 2 & 2 & 1 \\
\hline Herpes zoster virus & 3 & 3 & 3 & 4 \\
\hline Pseudomonas aeruginosa & 4 & 4 & 5 & 5 \\
\hline Staphylococcus epidermidis & 5 & 5 & 6 & 6 \\
\hline Toxoplasma gondii & 6 & 6 & 8 & 11 \\
\hline Cytomegalovirus & 7 & 7 & 4 & 3 \\
\hline Acanthamoeba sp. & 8 & 8 & 7 & 7 \\
\hline Onchocerca sp. & 9 & 10 & 17 & 22 \\
\hline Fusarium sp. & 10 & 9 & 9 & 8 \\
\hline Candida albicans & 11 & 11 & 20 & 13 \\
\hline E. coli & 12 & 13 & 12 & 9 \\
\hline Klebsiella sp. & 13 & 12 & 10 & 12 \\
\hline Mycobacterium tuberculosis & 14 & 14 & 13 & 10 \\
\hline Bacillus cereus & 15 & 15 & 11 & 14 \\
\hline Aspergillus fumigatus & 16 & 16 & 22 & 24 \\
\hline Corynebacterium & 17 & 17 & 14 & 15 \\
\hline Moraxella sp. & 18 & 18 & 27 & 26 \\
\hline Serratia marcescens & 19 & 19 & 16 & 18 \\
\hline Streptococcus pyogenes & 20 & 20 & 26 & 25 \\
\hline Proteus mirabilis & 21 & 21 & 18 & 20 \\
\hline Neisseria gonorrhea & 22 & 22 & 15 & 17 \\
\hline Ascomycota & 23 & 23 & 23 & 23 \\
\hline Aspergillus flavus & 24 & 24 & 21 & 16 \\
\hline Curvularia & 25 & 25 & 28 & 30 \\
\hline Alternaria & 26 & 26 & 29 & 28 \\
\hline Penicillium & 27 & 27 & 30 & 29 \\
\hline Treponema pallidum & 28 & 29 & 24 & 21 \\
\hline Acinetobacter sp. & 29 & 28 & 19 & 19 \\
\hline Aspergillus niger & 30 & 30 & 31 & 31 \\
\hline Streptococcus pneumonia & 31 & 31 & 25 & 27 \\
\hline $\begin{array}{l}\text { Staphylococcus } \\
\text { haemolyticus }\end{array}$ & 32 & 32 & 32 & 32 \\
\hline Leishmania sp. & 33 & 33 & 34 & 35 \\
\hline Cladosporium & 34 & 34 & 35 & 34 \\
\hline $\begin{array}{l}\text { Spirometra sp. } \\
\text { (previously Sparganum sp.) }\end{array}$ & 35 & 35 & 36 & 37 \\
\hline Bacillus subtilis & 36 & 36 & 33 & 33 \\
\hline Alcaligenes faecalis & 37 & 37 & 37 & 36 \\
\hline
\end{tabular}

*Highlighted cells indicate major differences from previous rankings. 